\title{
The effect of the supply chain exerting nhvsical stress on the microbiological status of bottled natural mineral water
}

\author{
${ }^{1}$ Renáta Tihanyi-Kovács - ${ }^{1}$ Erika Hanczné Lakatos - ${ }^{1}$ Balázs Ásványi - ${ }^{2}$ Péter Böröcz \\ ${ }^{1}$ Széchenyi István University, Faculty of Agricultural and Food Sciences, \\ Department of Food Sciences, Mosonmagyaróvár \\ ${ }^{2}$ Széchenyi István University, Audi Hungaria Faculty of Automotive Engineering, \\ Department of Logistics and Forwarding, Györ \\ tihanyi-kovacs.renata@sze.hu
}

\begin{abstract}
SUMMARY
Mineral water consumption increased dramatically in the last 30 years. One reason for this change lies in the changing consumer behaviour: consumers are increasingly recognizing the importance of healthy nutrition and appreciate the beneficial nutritional physiological properties of mineral water. Local mineral water harmonizes well with imported waters. Bottled mineral water may travel several hundred kilometres until it reaches consumers. In the present study, the dynamic mechanical vibration caused by transporting on public roads was simulated in laboratory vibration tests then samples were subjected to microbiological examinations in compliance with legislations currently in force. Due to this vibration, the initial microbe count increased by two orders of magnitude, while after terminating the 4-hour mechanical action it decreased gradually. Growing dynamics of microbes constituting the total germ count at $22{ }^{\circ} \mathrm{C}$ and $37^{\circ} \mathrm{C}$ were almost similar.
\end{abstract}

Keywords: mineral water, mechanical vibration, microbial status, change in microbe count

\section{INTRODUCTION}

No life exists without water and only freshwater is suitable for human consumption. Without food peoples may survive for weeks, but a water loss of $15 \%$ causes death in days. Consequently the water is vital for humans.

Water content of adult peoples is around $60-70 \%$. At born the ratio is higher, around $80 \%$ in infants. The ratio of water decreases over time. In elderly the water content of the body is only about $50 \%$.

An average people drinks more than 10001 fluids per year and body fluids flowing through the kidneys reaches the volume of 20001 per day. In circumstances of day to day, due to sweating, breathing, excretion and digestion averagely 2.41 of fluid leaves an adult body. The amount of water necessary to maintain the fluid balance varies from person to person and depends on the physical activity, functions of the body and the environmental conditions (temperature, humidity) (Maton et al. 1993).

Table 1 shows the amounts of recommended daily water consumption broken down to by age groups and gender.

Recommended daily water consumption in Europe (ml day $\left.{ }^{-1}\right)$

\begin{tabular}{lcccccc}
\hline Age group & $\begin{array}{c}\text { From food } \\
\text { women }\end{array}$ & $\begin{array}{c}\text { From drinks } \\
\text { women }\end{array}$ & In all & $\begin{array}{c}\text { From food } \\
\text { man }\end{array}$ & $\begin{array}{c}\text { From drinks } \\
\text { man }\end{array}$ & In all \\
\hline $2-3$ y & 390 & 910 & 1300 & 390 & 910 & 1300 \\
$4-8$ y & 480 & 1120 & 1600 & 480 & 1120 & 1600 \\
$9-13$ y & 570 & 1330 & 1900 & 630 & 1470 & 2100 \\
Up to 14 y & 600 & 1400 & 2000 & 750 & 1750 & 2500 \\
During pregnancy & 690 & 1610 & 2300 & - & - & - \\
During lactation & 600 & 2100 & 2700 & - & - & - \\
\hline
\end{tabular}

Source: European Food Safety Authority

Water plays an important role in living organisms:

- provides and maintains the blood circulation,

- plays a key role in the osmotic pressure of blood,

- controls the blood pressure,

- since most part of the blood is fluid, it plays an important role in the breakdown of food into nutrients,

- the absorption and transport of these to the proper site,

- it is also necessary for the maintenance of internal temperature.
Consumed water reaches all parts of our body. It absorbed from the digestive system to the blood, then it travels through the entire body and is temporarily stored in various organs and tissues where it passes the dissolved substances. Through substances the dissolved in it the effects of mineral waters will take place. During its recycling inside the body the water absorbs the metabolic products and transfers them thereby detoxifying the body (Net1, Csapó and Csapóné 2003). 
Fluid intake may take place mainly as the consumption of fluids, water, mineral water, juicy fruits, juices, beverages, milk and milk-containing drinks, teas and soups, among these the water is the most important. The drinking water always contains small amounts of dissolved minerals (calcium, magnesium, potassium, sodium) and some microelements (manganese, fluorine, iron, zinc).

Last years there was high demand in the mineral water market in Hungary (Figure 1). Yet few people know that only those waters can be considered to be mineral waters which contain at least $1000 \mathrm{mg}$ dissolved minerals per litre. „The mineral water in its natural state is a recognized water for human consumption originated from a protected underground water table or from one or several natural or artificially uncovered springs or wells. Due to its mineral and trace element content as well as other constituents it has beneficial health properties. The certification is issued by National Health Resorts and Spa Directorate General (OGYFI)" (Net2).

Figure 1: Trend in the mineral water consumption in Hungary between 1979-2016

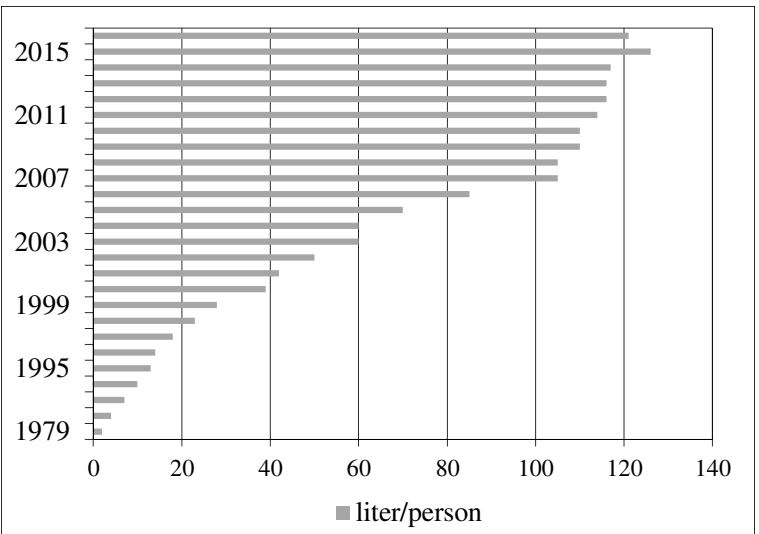

Numerous harmful bacteria and microorganisms may occur in the water, which make the regular inspections especially necessary. Two types of bacterial groups were found in the natural mineral water. The autochthonous (indigenous, native) bacteria constitute a part of the natural flora of water. These are mainly psychrotropic and multiply quickly in the bottled water. The other group is the allochtonous bacteria which are infectious and mainly get into the water during the process of bottling, but may also be present in the natural water. In the bottled water their viability is usually poor since not enough nutrients is present to support their surviving (Mavridou 1992).

Microbiota of water may be classified to 3 groups:

- the group of natural flora,

- the group of contaminating flora and,

- the group of soil bacteria.

The natural flora includes the Spirillium, Vibrio, Pseudomonas, Achromobacter and Chromobacterium species. Escherichia coli, Enterococcus faecalis and Clostridium perfringens are classified to the group of contaminant flora. Finally, the last group is the soil bacteria which includes the Bacillus, Streptomyces and Aerobacter species.

Previous scientific studies proved that the vibration - as a vertical stress affecting fluids - exerts negative influences on the physico-chemical properties of certain foods (Czerniewicz et al. 2006, Warmiňska et al. 2006, Paternoster et al. 2017). However no previous examinations studied the effect of mechanical vibration on the microbial status of foods. For the tests the water matrix was chosen considering its role and importance played in our nutrition. The aim of the study was to reveal the effects of dynamic mechanical vibration on the microbiote of natural mineral waters if any, and the kind of effect it exerts on the microbiote of natural mineral waters.

\section{MATERIALS AND METHODS}

\section{Dynamics of mechanical conditions}

To the measurements in this study vibration tests in laboratory simulated the dynamic stress of road transportation. The equipment used to this vibration test can be seen on Figure 2, namely a TIRA (TV59355) electro-dynamic vibration system and an Angelantoni AV600C climate chamber connected to the vibration armature. The later one ensured the temperature constantly on $23{ }^{\circ} \mathrm{C}$ during the tests. As preconditioning an ESPEC PR-3ST climate chamber was used to ensure $4{ }^{\circ} \mathrm{C}$ for specimens before tests.

Figure 2: Vibration table and connecting climate chamber

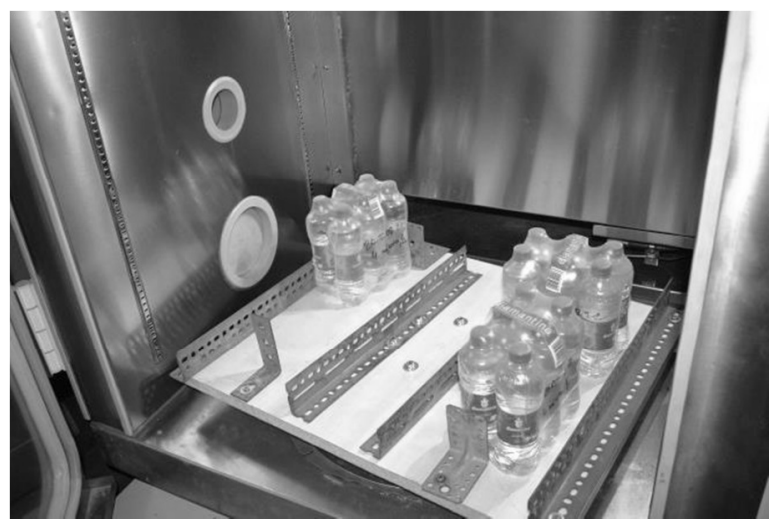

It is well known that a vehicle during distribution is a 6-DOF system (degrees of freedom) (Brandenburg and Lee 2001) the widely used simulation standards reproduces the moving of vertical direction. The reason of this is that the most intensive cited moving is coming from the vertical road track roughness (Böröcz and Singh 2017). Figure 3 shows series of field measured acceleration records in time history domain.

The commonly used laboratory vibration tests mainly focus on the control of the quality and integrity of packed units and products shipped via various distribution forms. The methods of these tests are to 
reproduce the real stochastic vibration with a broadband random vibration test in the range of 1-200 $\mathrm{Hz}$. In real transport this is the frequency band where the vibration has got a significant intensity. The most intensive vibration response of the cited vehicles parts such as suspension, tires and body structure can be found in this frequency range. To perform a vibration test these standards apply the so-called PSD (power spectral density) function of the random vibration, which is the fast Fourier transformation (FFT) of the stationary and random acceleration signal $(\mathrm{g})$. So, the feature of the moving is expressed by the PSD unit of $\mathrm{g}^{2} \mathrm{~Hz}^{-1}$ that can be perceived as the power of motion in the function of frequency $(\mathrm{Hz})$.

Figure 3: Field measured acceleration values

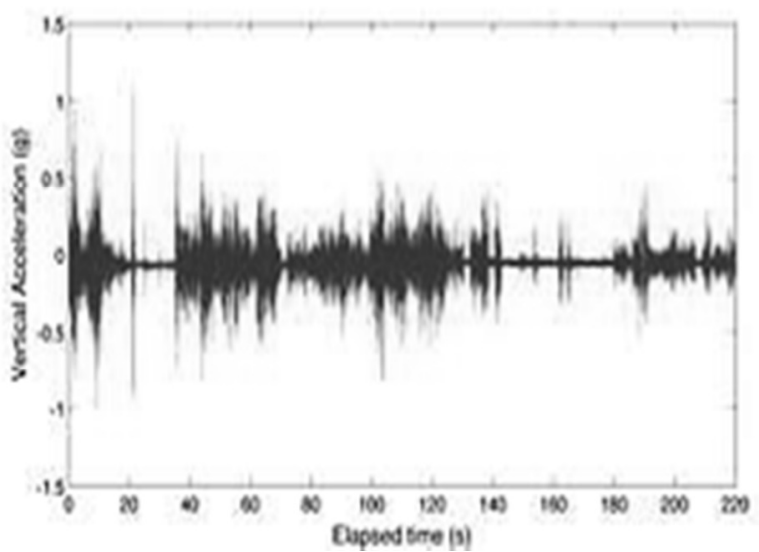

To the measurements of this study a well-known ASTM (American Society of Testing Materials) packaging vibration standard PSD profile was used. This ASTM D4169-16 (ASTM International 2016) applied a PSD profile of vibration for simulating the semi-trailer truck that has got steel spring sheets as suspension. The standard mentioned above recommends three different intensity of PSD plots (Low, Medium and High Level) to simulate the vibration circumstances, from which the medium level was used to the tests. Figure 4 shows these PSD plots of ASTM standard. Here has to be mentioned that it is also a practice to compare and examine the overall intensity of the PSD curves in the given frequency range beside the intensity of each frequency points. This is the square of area under the curve, expressed in RMS (Root Mean Square). The overall $G_{\mathrm{rms}}$ of applied medium PSD curve was 0.54

Seven packing units $(6 \times 0.51)$ of freshly bottled natural mineral water were shaken 3 times as follows: 1 packing unit was not shaken (Control), in a shaker 6 packing units were shaken for $4 \times 60 \mathrm{~min}$ in such way that every hour a packing unit was removed from the shaker and placed in a climatic cabinet adjusted to $+4{ }^{\circ} \mathrm{C}$ thus eliminating the temperature exerting influence on the increase in cell count. The remaining units were kept at $23{ }^{\circ} \mathrm{C}$ for 12 hours then shaking was repeated. After 2-2 shakings the samples were transferred for laboratory tests. 12 and 24 hours after the last shaking the samples were also plated.

\section{Figure 4: PSD curves of ASTM D4169 standard}

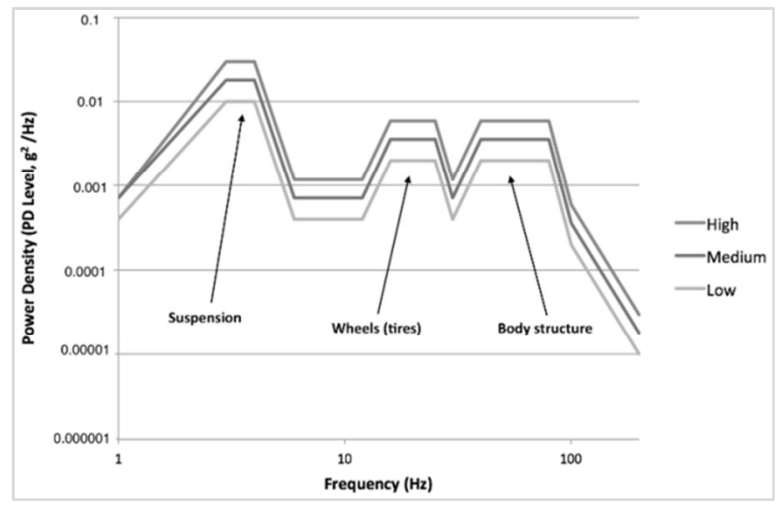

Naturally, the real distribution time de facto can be longer, but the PSD curves of these standards' PSD curve are so-called time-compressed. This means that the intensity of the curve is artificially amplified in order to get a shorter test time. The exact ratio of the amplification can only be set within wide limits due to the large number of variables Suggestions for commonly used test protocols for the test time are based on the mileage of the expected mileage in kilometres per minute. That is, in this case, an investigation period of 60 minutes can be considered as a distance of $480 \mathrm{~km}$.

\section{Microbiological tests}

Under current legislation in force [Min. Decr. 201/2001. (X. 25.)], coliform bacteria and Pseudomonas aeruginosa counts and total germ counts at $22{ }^{\circ} \mathrm{C}$ and $37{ }^{\circ} \mathrm{C}$ should be determined in the microbiological diagnostic performed on drinking waters and natural mineral waters. Besides determining the total germ count, in the presence of coliforms the number of Escherichia coli, Pseudomonas aeruginosa, Enterococcus (faecal Streptococcus) and sulphite reducing Clostridiums should also be determined the detailed bacteriological examination. These countings were performed by using classic culturing in compliance with standards as follows:

- Enumeration of microorganisms culturable at 22 ${ }^{\circ} \mathrm{C}$ and $37{ }^{\circ} \mathrm{C}$ (in compliance with standard MSZ EN ISO 6222:2000), and determination of colony number by inoculation of culture medium in compliance with standard ISO 6222:1999.

- Detection of Escherichia coli and coliform germs (in compliance with standard MSZ EN ISO 9308$1: 2001)$

- Detection of Enterococcus (in compliance with standard MSZ EN ISO 7899-2:2000)

- Determination of anaerobe (Clostridium) spore count (in compliance with standard MSZ EN 26461-2:1994)

- Determination of Pseudomonas aeruginosa (in compliance with standard MSZ EN ISO 16266:2008)

For easier illustration of orders of magnitudes the results obtained from colony counting were subjected to logarithmic transformation. 


\section{RESULTS}

In the first round the tests were performed with freshly bottled mineral water. Total germ counts of the initial samples at $22{ }^{\circ} \mathrm{C}$ and $37{ }^{\circ} \mathrm{C}$ were also under 1 CFU (Colony Forming Unit) $\mathrm{cm}^{-3}$ and no E. coli, Pseudomonas aeruginosa, Enterococcus and sulphite reducing Clostridium could be detected. Subsequently to shaking, the coliform count remained also under the detection limit. As both Table 2 and Figure 5 shows, increases with 2 orders of magnitude were measured in cell counts obtained after logarithmic transformation of total germ counts for both saprophyte and both allochtonous microbes after the forth 1-hour shaking.

Table 2

Change in total microbe counts of bottled mineral waters

\begin{tabular}{lcccc}
\hline \multirow{2}{*}{$\begin{array}{c}\text { Sampling } \\
\text { period } \\
\text { (h) }\end{array}$} & \multicolumn{2}{c}{ Cultured at $22^{\circ} \mathrm{C}$} & \multicolumn{2}{c}{ Cultured at $37^{\circ} \mathrm{C}$} \\
\cline { 2 - 5 } & $\begin{array}{c}\log _{10} \\
\mathrm{CFU}^{*} \mathrm{~cm}^{-3}\end{array}$ & $\begin{array}{c}\text { Standard } \\
\text { deviation }\end{array}$ & $\begin{array}{c}\log _{10} \\
\mathrm{CFU}^{*} \mathrm{~cm}^{-3}\end{array}$ & $\begin{array}{c}\text { Standard } \\
\text { deviation }\end{array}$ \\
\hline 0 & 0 & \pm 0 & 0 & \pm 0 \\
1 & 0 & \pm 0 & 0 & \pm 0 \\
14 & 0 & \pm 0 & 0 & \pm 0 \\
27 & 0 & \pm 0 & 0 & \pm 0 \\
40 & 2.45 & \pm 0.01 & 2.38 & \pm 0.01 \\
52 & 2.22 & \pm 0.02 & 2.07 & \pm 0.02 \\
64 & 2.10 & \pm 0.02 & 1.94 & \pm 0.03 \\
\hline
\end{tabular}

Note: $* \mathrm{CFU}=$ colony forming unit

Figure 5 clearly shows that after terminating the shaking (sample collection of 52- and 64-hour) the total microbe counts decreased slowly for both microbe groups.

Figure 5: Change in average microbe count in freshly bottled mineral waters during shaking

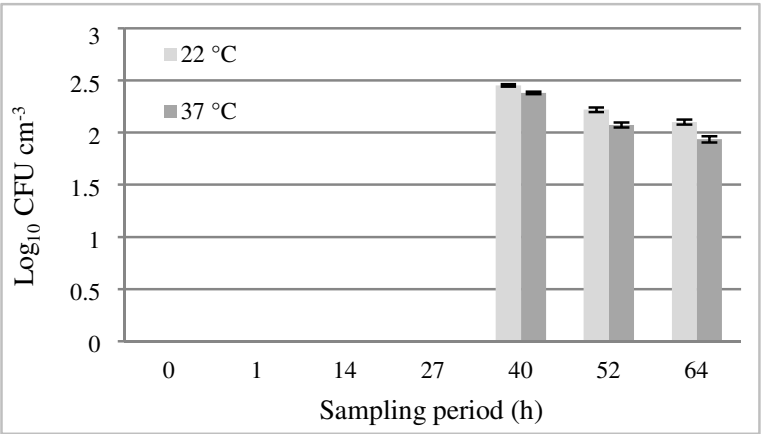

Note: $* \mathrm{CFU}=$ colony for ming unit

For the second testing samples with adjusted initial germ counts were used. For this purpose colonies cultured at $22{ }^{\circ} \mathrm{C}$ and $37{ }^{\circ} \mathrm{C}$ on YEA (Yeast Extract Agar) medium were used. Colonies picked from the surface of media were suspended in sterile dilution water. After homogenization 1-1 $\mathrm{ml}$ of suspension was transferred to 7 bottles of unopened mineral water $\left(500 \mathrm{~cm}^{3}\right)$.

Table 3 shows the log colony counts measured at the start, during shaking and the subsequent incubation. Note that the increase in colony count has already started after the $1^{\text {st }} 1$-hour shaking.

Table 3

Change in total germ count of mineral water with adjusted initial germ count during the test

\begin{tabular}{lcccc}
\hline \multirow{2}{*}{$\begin{array}{c}\text { Sampling } \\
\text { period } \\
\text { (h) }\end{array}$} & $\begin{array}{c}c \\
\text { cultured at } 22^{\circ} \mathrm{C}\end{array}$ & \multicolumn{2}{c}{ cultured at $37^{\circ} \mathrm{C}$} \\
\cline { 2 - 5 } & $\mathrm{CFU}^{*} \mathrm{~cm}^{-3}$ & $\begin{array}{c}\text { Standard } \\
\text { deviation }\end{array}$ & $\begin{array}{c}\text { Log }_{10} \\
\text { CFU }^{*} \mathrm{~cm}^{-3}\end{array}$ & $\begin{array}{c}\text { Standard } \\
\text { deviation }\end{array}$ \\
\hline 0 & 2.50 & \pm 0.04 & 2.86 & \pm 0.05 \\
1 & 4.40 & \pm 0.01 & 4.43 & \pm 0.01 \\
14 & 4.38 & \pm 0.00 & 4.36 & \pm 0.01 \\
27 & 4.41 & \pm 0.01 & 4.40 & \pm 0.01 \\
40 & 4.12 & \pm 0.01 & 3.40 & \pm 0.04 \\
52 & 3.46 & \pm 0.03 & 3.39 & \pm 0.02 \\
64 & 2.39 & \pm 0.04 & 2.69 & \pm 0.03 \\
\hline
\end{tabular}

Note: $* \mathrm{CFU}=$ colony forming unit

No E. coli, Pseudomonas aeruginosa, Enterococcus or sulphite reducing Clostridium could be detected in this course of test. Similarly to the examination of unopened freshly bottled waters increases of 2 orders of magnitude were found in infected samples regarding total germ counts cultured at $22{ }^{\circ} \mathrm{C}$ and $37{ }^{\circ} \mathrm{C}$. After the $2^{\text {nd }}$ and $3^{\text {rd }}$ one-hour shaking no changes were detected in total aerob mesophil count and decrease was observed after the $4^{\text {th }}$ shaking (Figure 6) however after the 24-hour incubation germ numbers returned to the initial values for both cultures grown at the two temperatures.

Figure 6: Change in average colony count of inoculated samples during shaking

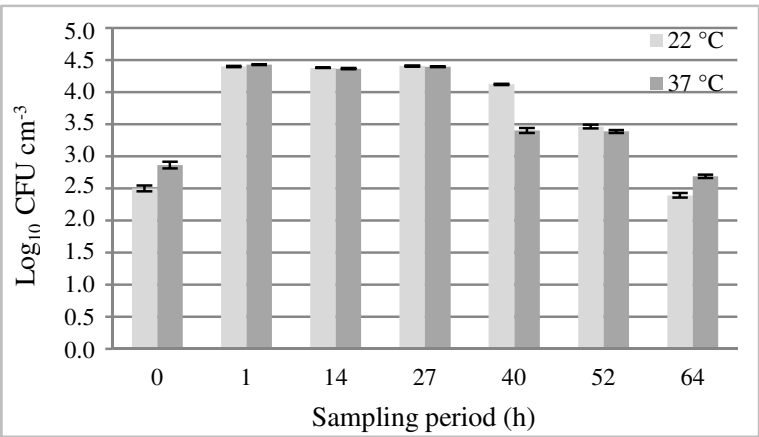

Note: $* \mathrm{CFU}=$ colony for ming unit

\section{DISCUSSION}

The results of the present study suggest that the dynamic mechanical vibration affects the microbial status of bottled mineral water and this effect occurs as an increase in the total colony counts. Regarding changes in colony counts no differences found in total microbe counts cultured at $22{ }^{\circ} \mathrm{C}$ and $37{ }^{\circ} \mathrm{C}$. Tests performed at the medium performance level of standard ASTM D4169-16 revealed an increase with 2 orders of magnitude in the germ counts. After the termination of mechanical effect the cell count started to decrease however the present study could not 
determine the period to the steady state. It should be taken into account that increases in cell counts after the zero values do not mean the lack of living cells in the given sample, instead that the living cells were present in numbers below the detection limit of the standard test.

The results suggest that the increase in germ counts may be the due to the response of microbes to the mechanical stress.

Further studies are necessary to reveal that this change in microbe count occurs in the shaking or the followed incubation period and the length or the intensity of shaking has a higher importance. Further testing will also be performed under extreme temperature parameters and UV radiation.

\section{ACKNOWLEDGEMENT}

This paper is supported by the Project of EFOP3.6.1-16-2016-00017 Internationalisation, initiative to establish a new of researchers and graduates, and development of knowledge and technological transfer as instruments of intelligent specialisation at Széchenyi István University.

\section{REFERENCES}

ASTM (2016): D4169-16 Standard Practice for Performance Testing of Shipping Containers and Systems. ASTM International. West Conshohocken. PA.

Böröcz, P.-Singh, S. P. (2017): Measurement and analysis of delivery van vibration levels to simulate package testing for parcel delivery in Hungary. Packag Technol Sci. 1. 11: DOI: $10.1002 / \mathrm{pts} .2327$

Brandenburg, R. K.-Lee, J. J. L. (2001): Fundamentals of Packaging Dynamics. L.A.B. Equipment.

Czerniewicz, M.-Kruk, A.-Kiełczewska, K. (2006): Storage stability of raw milk subjected to vibration. Pol. J. Food Nutr. Sci. 56. 15: 65-70.

Csapó J.-Csapóné Kiss Zs. (2003): 1. A víz és ásványi anyagok. A víz. Élelmiszer-kémia. Mezőgazda Kiadó. Budapest. 19

Maton, A.-Hopkins, J.-McLaughlin, Ch. W.-Johnson, S. -Warner, M. Q.-LaHart, D.-Wright, J. D. (1993): Human Biology and Health. Englewood Cliffs. Prentice Hall. New Jersey. USA.

Mavridou, A. (1992): Study of the bacterial flora of a noncarbonated natural mineral water. Journal of Applied Bacteriology. 73: 355-361.

MSZ EN 26461-2:1994 Water quality. Detection and enumeration of the spores of sulfite-reducing anaerobes (clostridia). Part 2: Method by membrane filtration.

MSZ EN ISO 16266:2008 Water quality. Detection and enumeration of Pseudomonas aeruginosa. Method by membrane filtration (ISO 16266:2006)
MSZ EN ISO 6222:2000 Water quality. Enumeration of culturable micro-organisms. Colony count by inoculation in a nutrient agar culture medium (ISO 6222:1999).

MSZ EN ISO 7899-2:2000: Water quality. Detection and enumeration of intestinal enterococci. Part 2: Membrane filtration method (ISO 7899-2:2000).

MSZ EN ISO 9308-1:2001 Water quality. Detection and enumeration of Escherichia coli and coliform bacteria. Part 1: Membrane filtration method (ISO 9308-1:2000).

Net1: http://asvanyvizek.hu/index.php/eletmod/mennyi-folyadekravan-szuksegunk

Net2: www.ofe.hu

Net3: http://asvanyvizek.hu/index.php/erdemes-tudni/asvanyvizfogyasztasi-adatok/item/24-asvanyviz-fogyasztasmagyarorszagon

Paternoster, A.-Van Camp, J.-Vanlanduit, S.-Springael, J.-Braet, J. (2017): The performance of beer packaging: Vibration damping and thermal insulation. Food Packaging and Shelf Life. 11: 9197.

Warmiňska, M.-Kruk, A.-Brandt, W. (2006): Effect of vibration frequency and exposure time on the technological usability os fresh milk. Pol. J. Food Nutr. Sci. 56. 15: 247-251. 